\title{
Recent advances in the investigation of pancreatic inflammation induced by large doses of basic amino acids in rodents
}

\author{
Balázs Kui ${ }^{1}$, Zsolt Balla ${ }^{1}$, Eszter T Végh ${ }^{1}$, Petra Pallagi ${ }^{1}$, Viktória Venglovecz², Béla Iványi ${ }^{3}$, \\ Tamás Takács ${ }^{1}$, Péter Hegyi ${ }^{1}$ and Zoltán Rakonczay $\mathrm{Jr}^{1}$
}

It has been known for approximately 30 years that large doses of the semi-essential basic amino acid L-arginine induce severe pancreatic inflammation in rats. Recently, it has been demonstrated that L-arginine can also induce pancreatitis in mice. Moreover, other basic amino acids like L-ornithine and L-lysine can cause exocrine pancreatic damage without affecting the endocrine parenchyma and the ducts in rats. The utilization of these noninvasive severe basic amino acid-induced pancreatitis models is becoming increasingly popular and appreciated as these models nicely reproduce most laboratory and morphological features of human pancreatitis. Consequently, the investigation of basic amino acid-induced pancreatitis may offer us a better understanding of the pathogenesis and possible treatment options of the human disease.

Laboratory Investigation (2014) 94, 138-149; doi:10.1038/labinvest.2013.143; published online 23 December 2013

KEYWORDS: basic amino acids; L-arginine; L-lysine; L-ornithine; pancreas; pancreatitis

The most frequently utilized rodent acute pancreatitis (AP) models to study the pathogenesis and treatment options of this severe disease include the secretagogue (cerulein)induced models, the retrograde duct infusion models, the choline-deficient ethionine-supplemented diet-induced model, and the L-arginine-induced model. ${ }^{1,2}$ Out of the four models, the cerulein and duct infusion models are more commonly used and better characterized, but their pathophysiology is still unclear. Much less is known about the L-arginine-induced AP model, despite the fact that the damaging effect of a large intraperitoneal (i.p.) dose $(5 \mathrm{~g} / \mathrm{kg})$ of L-arginine on pancreatic acinar cells in rats was noted in 1984 by Mizunuma et $a l,{ }^{3}$ soon after the description of the other more commonly used pancreatitis models. ${ }^{4-6}$

Close to 10 years have passed since our previous review was published on the L-arginine-induced AP model. ${ }^{7}$ Since then, this noninvasive severe necrotizing AP model has become increasingly appreciated and more thoroughly investigated. Therefore, the numerous advances in the field justify an overview of recent developments. For the most part, this review concentrates on English language publications that appeared since our previous review on
L-arginine-induced AP. We will also summarize the advantages and disadvantages of using the basic amino acid-induced pancreatitis models.

\section{METABOLISM OF L-ARGININE}

Figure 1 shows a brief overview of L-arginine metabolism. There are two key enzymes involved in the metabolism of this semi-essential amino acid: nitric oxide synthase and arginase. ${ }^{8}$ Nitric oxide synthase has three isoforms: the constitutive endothelial and neuronal and an inducible form. These catalyze the conversion of $\mathrm{L}$-arginine to nitric oxide and L-citrulline. Arginase, which has two isoforms (types I and II), is a key enzyme in the urea cycle and hydrolyzes L-arginine to L-ornithine and urea. Of note, L-ornithine is a precursor of polyamines (putrescine, spermidine, and spermine) that are aliphatic polycations involved in numerous cellular processes.

\section{NOT ONLY L-ARGININE BUT ALSO OTHER BASIC AMINO ACIDS CAN INDUCE AP}

The dosing of L-arginine (higher single or lower double-dose injections) to induce AP in rats has been thoroughly reviewed previously, and hence we will not discuss this issue in the

${ }^{1}$ First Department of Medicine, University of Szeged, Szeged, Hungary; ${ }^{2}$ Department of Pharmacology and Pharmacotherapy, University of Szeged, Szeged, Hungary and ${ }^{3}$ Department of Pathology, University of Szeged, Szeged, Hungary

Correspondence: Dr Z Rakonczay, MD, PhD, DSc, First Department of Medicine, University of Szeged, PO Box 427, Szeged H-6701, Hungary.

E-mail: rakonczay.zoltan@med.u-szeged.hu

Received 24 August 2013; revised 13 November 2013; accepted 19 November 2013 


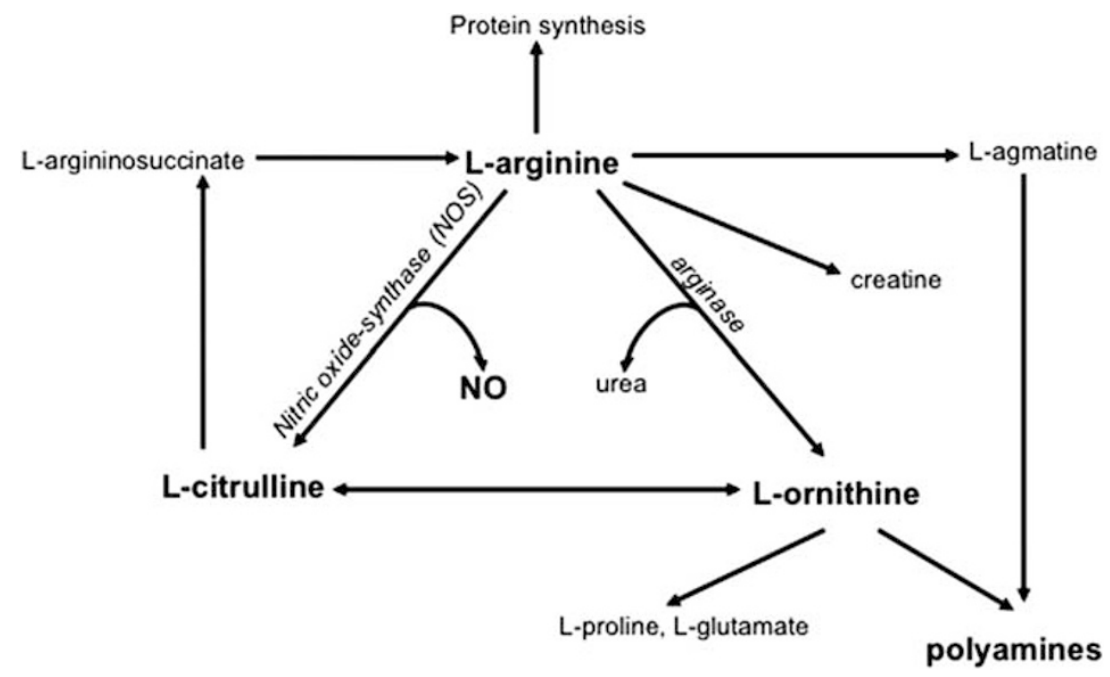

Figure 1 The metabolism of L-arginine. The diagram shows key pathways of L-arginine metabolism.

current publication. For details, please check an earlier manuscript by Hegyi et al. ${ }^{7}$ Importantly, recently it has been demonstrated that not only L-arginine but also other basic amino acids like L-ornithine $(3 \mathrm{~g} / \mathrm{kg})^{9}$ and L-lysine $(2 \mathrm{~g} / \mathrm{kg})^{10}$ can cause exocrine pancreatic damage without affecting the endocrine parenchyma and the ducts. Therefore, in this paper, we collectively refer to these AP models as those induced by basic amino acids.

The i.p. injection of $3 \mathrm{~g} / \mathrm{kg}$ L-histidine did not affect the rat pancreas; ${ }^{11}$ however, according to a recent presentation at the 45th European Pancreatic Club meeting in Zurich, the administration of $2 \times 4 \mathrm{~g} / \mathrm{kg}$ L-histidine induced AP in mice. ${ }^{12}$ It is possible that $>3 \mathrm{~g} / \mathrm{kg}$ i.p. doses of L-histidine may cause AP in rats as well, but we were reluctant to test the effects of larger doses of L-histidine, as the solubility of L-histidine in physiological saline is not as good as that of other basic amino acids and animals were already loaded with high volumes of fluid when injected with the $3 \mathrm{~g} / \mathrm{kg}$ dose. ${ }^{11}$ Notably, it is interesting that basic amino acids with an aliphatic side chain (Figure 2) seem to be more effective at inducing AP.

\section{LARGE INTRAPERITONEAL DOSES OF L-ARGININE ALSO INDUCE AP IN MICE}

A major catalyst in the investigation of L-arginine-induced AP was provided by Dawra et al. ${ }^{13}$ For decades, researchers have thought that L-arginine could only induce pancreatitis in rats, but not in mice. In fact, a single i.p. dose of $4 \mathrm{~g} / \mathrm{kg}$ L-arginine has no effect on the mouse pancreas. However, Dawra et al $^{13}$ showed that the model could also be induced in mice by using much higher doses. Most commonly, $2 \times 4 \mathrm{~g} / \mathrm{kg}$ $\mathrm{L}$-arginine- $\mathrm{HCl}(8 \%, \mathrm{pH}=7.0-7.2)$ is administered at an interval of $1 \mathrm{~h} ;{ }^{13,14}$ however, $2 \times 2 \mathrm{~g} / \mathrm{kg},{ }^{15,16} 1 \times 8 \mathrm{~g} / \mathrm{kg}$, ${ }^{17}$ or even higher doses such as $2 \times 4.7 \mathrm{~g} / \mathrm{kg}^{18}$ or $2 \times 5 \mathrm{~g} / \mathrm{kg}^{19}$ have been reported (Table 1). We do not recommend using $2 \times 2 \mathrm{~g} / \mathrm{kg}$ or a single i.p. dose of $8 \mathrm{~g} / \mathrm{kg}$ of $\mathrm{L}$-arginine to induce $\mathrm{AP}$, as the earlier dose is too low (in accordance with Dawra et al, ${ }^{13}$ we do not see any pancreatic damage) and the latter single high dose would cause significant mortality. In contrast to that reported by Huang et al, ${ }^{20}$ a single i.p. injection of $4 \mu \mathrm{g} / \mathrm{kg}$ L-arginine will not induce AP in mice and we could only think of this as being a typo. Bedrosian et $a^{21}$ also administered an unusually low dose of L-arginine to induce AP that is 100 -fold less $(2 \times 40 \mathrm{mg} / \mathrm{kg})$ than the most commonly used dose. Looking carefully at their data, we could not see much histological damage (confirmed by the near 100\% acinar viability) in the animals treated with L-arginine; however, in mice depleted of dendritic cells (CD11c.DTR mice treated with $4 \mathrm{ng} / \mathrm{g}$ diphtheria toxin i.p.), a marked tissue injury ( $\sim 85 \%$ cell damage) was detected after L-arginine treatment. It may be that the diphtheria toxin used to induce dendritic cell depletion or the dendritic cell depletion itself somehow sensitizes the mouse pancreas to L-arginine.

Unfortunately, the borderline between the effective and toxic doses of $\mathrm{L}$-arginine is rather narrow and it is difficult to
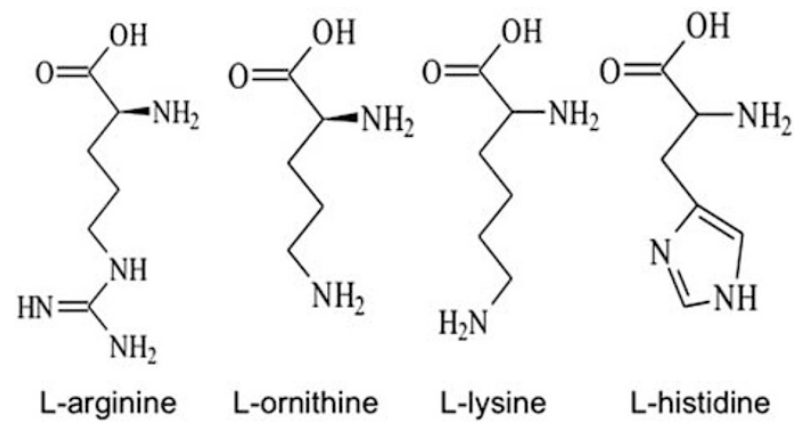

Figure 2 Basic amino acids inducing acute pancreatitis in rodents. Large intraperitoneal doses of L-arginine, L-ornithine, and L-lysine, but not L-histidine, have been shown to induce severe acute pancreatitis in rats. Administration of L-arginine and L-histidine have also been demonstrated to induce experimental pancreatitis in mice. 

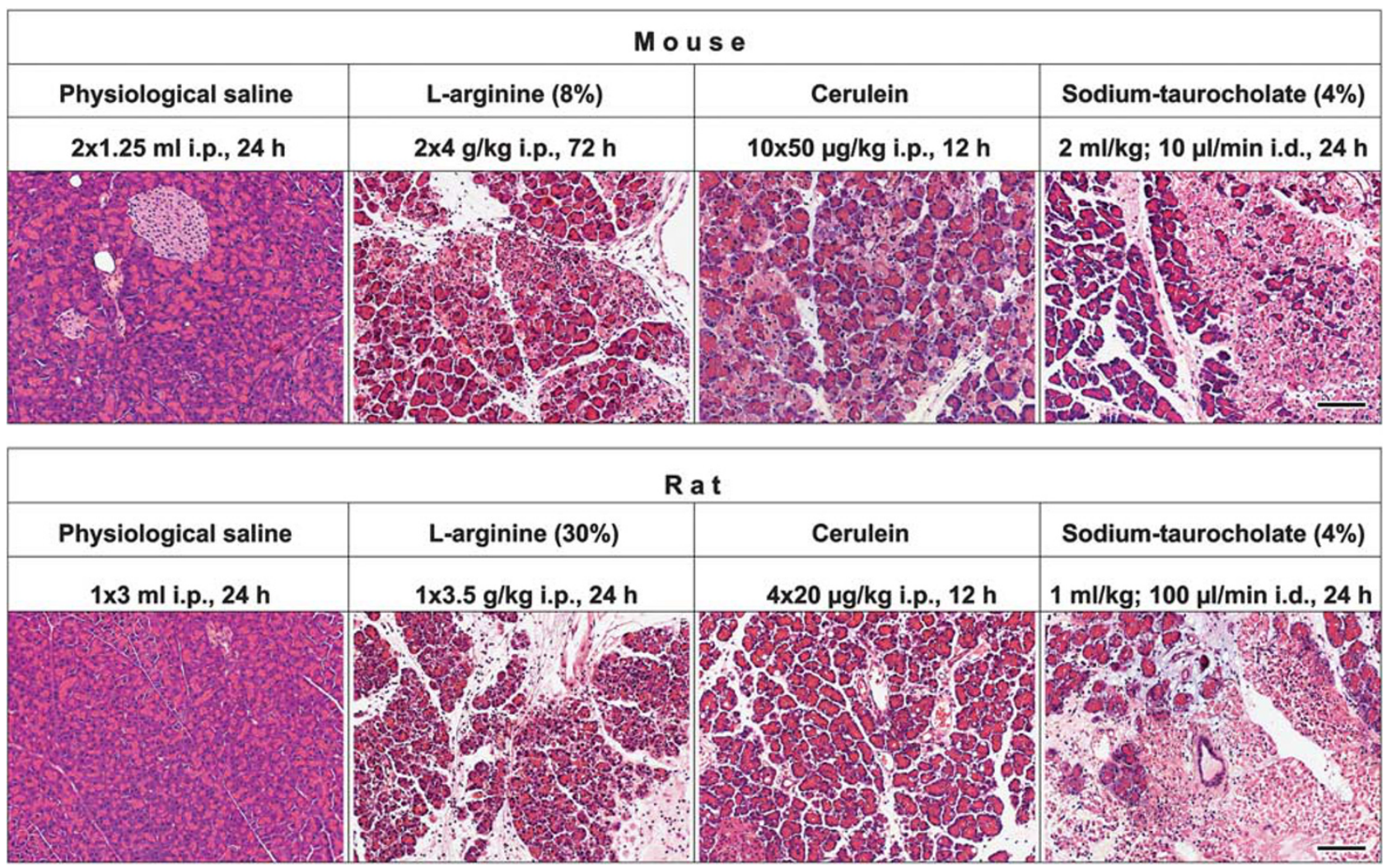

Figure 3 Histological pictures of some commonly used acute pancreatitis models. The pictures show representative hematoxylin and eosin-stained pancreatic sections from mice and rats treated intraperitoneally with physiological saline, L-arginine, or cerulein, or intraductally with $4 \%$ sodium taurocholate. Animals were killed at 12,24 , or $72 \mathrm{~h}$ after the AP induction as indicated. Both L-arginine and sodium taurocholate administration cause severe necrotizing pancreatitis in rats and mice. Cerulein treatment causes mild edematous pancreatitis in rats and severe necrotizing pancreatitis in mice. i.p., intraperitoneally, i.d., intraductally. Scale bars $=100 \mu \mathrm{m}$.

titrate the severity of L-arginine-induced AP in mice. Grading of disease severity by varying the dose of the basic amino acid (especially with L-arginine) is easier in rat. ${ }^{7}$ Whereas in rats mortality is rarely seen with standard L-arginine doses (at least in our hands), the i.p. injection of $2 \times 4 \mathrm{~g} / \mathrm{kg}$ L-arginine reportedly kills $\sim 5-7 \%$ of mice. ${ }^{14}$ Notably, mortality usually occurs within a few hours after the injections, before the development of AP and may be because of metabolic complications (like severe metabolic acidosis) or central nervous system effects.

\section{CHARACTERISTIC MORPHOLOGICAL AND LABORATORY FEATURES OF BASIC AMINO ACID-INDUCED AP}

Whereas low i.p. doses of basic amino acids result in virtually no pancreatic damage, high doses of basic amino acids induce typical changes of AP. The pancreas usually appears edematous from 18 to $36 \mathrm{~h}$, its peak being at $18-24 \mathrm{~h}$ in rats. ${ }^{9}$ Ascites and adhesions of organs are seen from 4 to $6 \mathrm{~h}$ (peaking at $24 \mathrm{~h}$ ). Occasionally, yellow-white foci indicative of chalky fat necrosis are detected in the mesentery of the bowels and retroperitoneum at $24-72 \mathrm{~h}$. Pancreatic size is significantly decreased (because of the massive necrosis) from $72 \mathrm{~h} v s$ the control animals treated with physiological saline.
Signs of mild acute tubular necrosis in the kidney and mild respiratory distress syndrome could be observed from 9 to 36 h. ${ }^{9}$ Pulmonary inflammation was not accompanied by any significant deterioration in respiratory function resulting from L-arginine-induced AP. ${ }^{22}$ Dilated small and large bowels suggesting functional ileus is apparent at $48 \mathrm{~h}$ to 1 week after injection of basic amino acids.

Characteristic histological features of AP induced by basic amino acids in the rat and mouse are demonstrated in Figure 3. Note that although the most commonly used AP models have a rather different histological appearance (Figure 3), similar to other AP models and the human disease, excessive doses of basic amino acids cause signs of pancreatic edema, cell damage, and inflammation, ${ }^{7}$ whereas interestingly cell damage without inflammation was reported by Kitajima and Kishino ${ }^{23}$ in case of L-lysine. Some people have detected pancreatic hemorrhage $e^{15,20,24-28}$ in L-arginineinduced AP, but in our hands we have never seen such alteration. The predominant form of death in acinar cells is necrosis, and apoptosis is less pronounced. ${ }^{29,30}$ The distribution of basic amino acid-induced pancreatic damage is homogenous in rats and is more patchy in mice (Figure 3), but ducts and islets are spared from injury in both species. 
Pancreatic regeneration starts rather quickly after the massive cell death. Collagen deposition (detected by Sirius red staining) was noted at 96 and $120 \mathrm{~h}$ after L-arginine administration in mice. ${ }^{13}$ Part of the damaged acinar parenchyma is eventually replaced by fatty tissue. ${ }^{9,10}$ Histological changes of $\mathrm{L}$-arginine-induced AP start at $\sim 6 \mathrm{~h}$ and peak at $\sim 72 \mathrm{~h}$ in mice, a process that is delayed as compared with that observed in rats where vacuole-like structures are already evident at 2 h. ${ }^{9,10,13,14}$ Compared with other models such as cerulein- or bile acid-induced AP, histological changes appear at a somewhat slower pace. The histological appearance of AP induced by various basic amino acids is similar and slightly differ in their time course (Figure 3 ).

Notably, despite the massive pancreatic necrosis and markedly reduced pancreatic amylase activity, serum amylase activity is usually not dramatically increased, but amylase activity in the ascites is greatly elevated in these AP models. ${ }^{9,10}$ In addition, whereas in cerulein- or bile acid-induced $\mathrm{AP}$, pancreatic trypsinogen and nuclear factor- $\kappa \mathrm{B}$ (NF- $\kappa \mathrm{B}$ ) activation are early events, in basic amino acid-induced AP these seem to occur at a later phase of the disease. ${ }^{9,10}$ Notably, L-arginine administration causes a prolonged activation of trypsinogen, rather than being transient. ${ }^{9,10,13}$

Kong et $a l^{31}$ recently reported an innovative way to diagnose pancreatic damage. They hypothesized that pancreas-specific miRNAs (like miR-216a) may leak into the circulation from injured pancreatic cells. Indeed, the plasma concentrations of miR-216a were markedly increased $24-48 \mathrm{~h}$ after the i.p. administration of $2 \times 2.5 \mathrm{~g} / \mathrm{kg}$ L-arginine, whereas the non-pancreas-specific miR-16 concentrations remained unchanged (indicating that pancreatic injury does not lead to general increase of plasma miRNAs).

\section{METABOLIC ALTERATIONS IN L-ARGININE-INDUCED PANCREATITIS}

It has been reported that the response of rodents to i.p. $\mathrm{L}$-arginine and L-lysine can be variable. ${ }^{10,32}$ Sprague-Dawley rats treated with lower doses $(1 \mathrm{~g} / \mathrm{kg})$ of $\mathrm{L}$-arginine showed marked uniformity in the outcome determined by histopathology (basically no marked changes), clinical chemistry, and nuclear magnetic resonance spectral profiles, but in the high-dose $(4 \mathrm{~g} / \mathrm{kg})$ group, weak, normal, and strong responders were detected. ${ }^{32}$ The weak responders had minimal alterations $v s$ the saline-treated control group, and the strong responders died (most likely because of metabolic alterations and not AP). In the first $8 \mathrm{~h}$ after the injection of $\mathrm{L}$-arginine, Bohus et $a \mathrm{l}^{32}$ found extensive excretion of arginine, ornithine, and urea (indicative of enhanced urea cycle activity), and elevated urinary levels of glutamine and glutamate (indicative of higher transamination activity). By $48 \mathrm{~h}$, the authors highlighted a notable enhancement of the excretion of the gut microbial metabolites, creatine, creatinine, phenylacetylglycine, and 4-cresol metabolites (derived from metabolism of aromatic amino acids phenylalanine and tyrosine as part of the putrefactive processes mediated by the colonic microflora).
A metabolomic approach to disease investigation was also carried out by a Japanese group using gas chromatography/ mass spectrometry who looked at changes in metabolite levels in two (cerulein- and L-arginine-induced) mouse AP models. ${ }^{18}$ In L-arginine-induced AP, a total of 120 and 133 metabolites were detected in the sera and pancreatic tissues, respectively. ${ }^{18}$ Out of these metabolites, 20-46 showed significant changes at $48-72 \mathrm{~h}$ after L-arginine injection. Chen et $a l^{33}$ went even further to perform quantitative organellar proteomics analysis of rough endoplasmic reticulum (ER) from the pancreata of control and acute pancreatititic rats. In all, 37 rough ER proteins ( 25 unique in L-arginine-induced AP, 6 unique in cerulein-induced AP, and 6 common in both AP models) showed significant changes during AP including translational regulators and digestive enzymes, but only mild changes were found in some ER chaperones.

Not surprisingly, i.p. administration of L-arginine resulted in significantly increased blood concentration of the basic amino acid that lasted for several hours after the injection. If we take a look at changes in serum L-arginine concentrations, it is evident that mice $^{13}$ metabolize $\mathrm{L}$-arginine faster than rats. ${ }^{9}$ The latter fact may be one of the reasons why higher doses of $\mathrm{L}$-arginine are needed to induce pancreatic damage in mice. The i.p. injection of $3.5 \mathrm{~g} / \mathrm{kg}$ L-arginine in rats resulted in much greater increases in serum ornithine $v s$ citrulline concentration in rats. ${ }^{9}$ This indicates that a large dose of L-arginine is mainly metabolized via arginase rather than nitic oxide synthase. The irreversible partial inhibition of arginase activity by (+)-S-2-amino-6-iodoacetamidohexanoic acid significantly reduced the severity of L-arginine-induced $\mathrm{AP}^{34}$ This may be because of the reduced conversion of $\mathrm{L}$-arginine to L-ornithine by arginase that can be detrimental in L-arginineinduced AP.

Metabolic alterations can also have an effect on the severity of amino acid-induced pancreatitis. Czakó et al ${ }^{35}$ have found that hyperlipidemia induced by a $3 \%$ cholesterol-rich diet aggravates L-arginine-induced necrotizing $\mathrm{AP}$ in rats. The pancreatic $\mathrm{Mn}$-superoxide dismutase, $\mathrm{Cu} / \mathrm{Zn}$-superoxide dismutase, glutathione peroxidase, and constitutive nitric oxide synthase activities and total glutathione levels were significantly reduced, whereas the catalase, inducible nitric oxide synthase, and NF- $\kappa \mathrm{B}$ DNA-binding activities were significantly increased in the animals with necrotizing AP on the cholesterol diet as compared with those with pancreatitis and on a normal diet. ${ }^{35}$

\section{PATHOMECHANISM OF BASIC AMINO-INDUCED AP}

A concise summary of studies investigating the pathogenesis of basic amino-induced AP is provided in Figure 4.

\section{Mitochondrial Injury}

A recent study by our group has shown that the i.p. injection of $2 \mathrm{~g} / \mathrm{kg}$ L-lysine induces severe mitochondrial injury in rats. ${ }^{10}$ Electron microscopy and diaphorase staining revealed that massive enlargement of pancreatic (but not hepatic) 


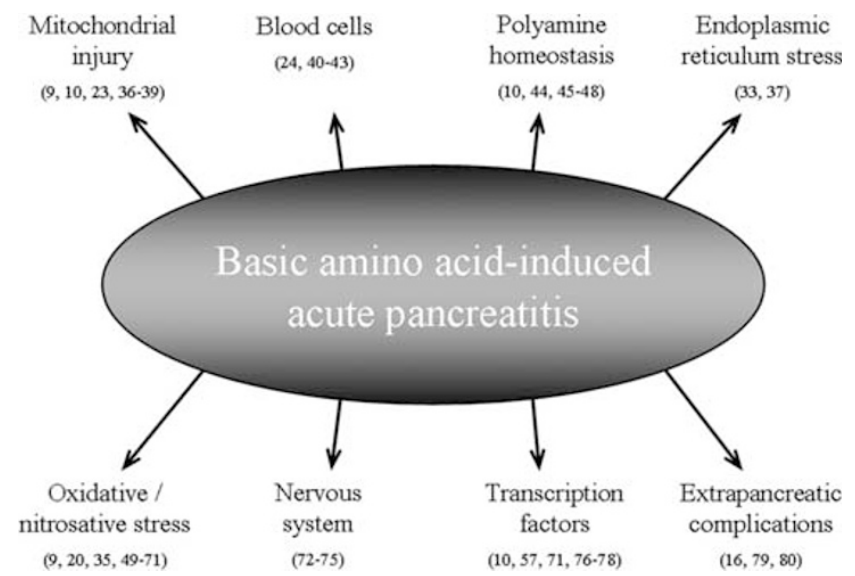

Figure 4 Summary of studies investigating the pathogenesis of basic amino-induced acute pancreatitis. The numbers in the parentheses show the corresponding references.

mitochondria is already evident at early time points after disease induction. Similar findings were reported previously in response to administration of $4 \mathrm{~g} / \mathrm{kg}$ L-lysine- $\mathrm{HCl},{ }^{23,36}$ although in our hands the latter dose caused considerable mortality. In fact, the $4 \mathrm{~g} / \mathrm{kg}$ dose is close to the reported $\mathrm{LD}_{50}$ value $(4019 \mathrm{mg} / \mathrm{kg}$ if given i.p.) for rats. It is likely that early vacuole-like structures in the L-arginine- (eg, see Figure 1B of Kubisch et $a^{37}$ ) and L-ornithine-induced AP models ${ }^{9}$ are also, at least in part, a consequence of mitochondrial injury. Importantly, basic amino acid-induced mitochondrial damage preceded both pancreatic trypsinogen and NF- $\kappa \mathrm{B}$ activation. ${ }^{9,10}$ Experiments on isolated pancreatic mitochondria demonstrated that L-lysine impairs the ability of organelles to restore normal potential and respiration after addition of ADP, which suggests that the function of ATP synthase may be inhibited. Similarly, pancreatic mitochondria isolated from cerulein-treated rats showed inhibition of mitochondrial respiration and decreased mitochondrial membrane potential. ${ }^{38}$ In addition, cholecystokinin octapeptide (which induces mild edematous pancreatitis in rats) caused a pronounced mitochondrial membrane potential depolarization in pancreatic acinar cells at supramaximal concentrations, ${ }^{39}$ which is expected to decrease ATP production. Overall, it is likely that mitochondrial injury may play a critical role in the development of pancreatic tissue damage caused by stressors causing AP. Thus, mitochondria may be targets in both the prevention and treatment of pancreatitis. We believe that basic amino acidinduced AP models may be particularly useful in investigating the involvement of mitochondria in the pathogenesis of severe necrotizing pancreatitis.

\section{The Severity of L-Arginine-induced Pancreatitis is Modulated by Blood Cells}

Lately, the modulation of AP severity by blood cells has received much attention. Depletion of platelets with antiglycoprotein- $1 \mathrm{~b} \alpha$ antibody significantly reduced the extent of
L-arginine-induced pancreatic edema, acinar cell necrosis, and hemorrhage, and protected against L-arginine-provoked damage of the tissue microarchitecture in mice. ${ }^{24}$ Furthermore, depletion of platelets decreased the pancreatitis-induced elevation of pancreatic myeloperoxidase activity and the number of extravascular neutrophils.

A marked increase in serum thrombopoietin (TPO) levels was detected in the mouse L-arginine-induced AP model, and TPO levels significantly correlated with the extent of acinar cell necrosis. ${ }^{40}$ Administration of recombinant TPO significantly exacerbated L-arginine-induced tissue injury and blockade of TPO significantly reduced the necrosis of acinar cells. Furthermore, pancreatic regeneration was decreased after TPO treatment in AP mice, but increased after the antiTPO antibody treatment.

The involvement of white blood cells in L-arginine-induced $\mathrm{AP}$ is not at all surprising, as the disease is accompanied by a marked inflammatory response. In fact, the cell adhesion molecule P-selectin was shown to mediate neutrophil rolling and recruitment in AP, and inhibition of this protein mediating leukocyte-endothelium interactions by immunoneutralization protected against L-arginine-induced pancreatic tissue injury. ${ }^{41}$ Induction of AP by L-arginine in mice was also dependent on macrophage migration by CCL2 via the CCR2 receptor. ${ }^{42}$ Surprisingly, the immunosuppressive drug tacrolimus was claimed to increase the severity of L-arginine-induced AP in rats, ${ }^{43}$ but the provided data do not necessarily support this conclusion. Actually, repetitive subcutaneous administration of tacrolimus did not seem to significantly alter serum amylase activity, pancreatic edema, inflammatory infiltration, and atrophy in the late phases of AP.

\section{Alteration of Polyamine Homeostasis}

Polyamines are essential in the function of cells. Among the tissues in the mammalian body, the pancreas has the highest concentration of the natural polyamine spermidine. ${ }^{44}$ The pancreas is rather sensitive to acute decreases in polyamine levels, and activation of polyamine catabolism in transgenic rats and mice overexpressing spermidine/spermine $\mathrm{N}^{1}$-acetyltransferase, the key enzyme in polyamine catabolism, results in severe AP. ${ }^{45,46}$ Although L-ornithine is a direct precursor of polyamines, interestingly, the pancreatic levels of these aliphatic polycations (especially spermidine) are decreased in L-arginine-- ${ }^{47}$ L-ornithine- ${ }^{48}$ and L-lysine-induced ${ }^{10}$ AP. In all basic amino acid-induced (and other) experimental AP models, polyamine depletion is likely to be mediated by the activation of spermidine/spermine $\mathrm{N}^{1}$-acetyltransferase. Although the administration of metabolically stable $\alpha$-methylated polyamine analogs did not reverse the pancreatic depletion of natural polyamines, they reduced the severity of L-arginine-induced $\mathrm{AP}^{47}$ whereas they did not have an effect on L-ornithine-induced $\mathrm{AP}^{48}$ The reasons for this discrepancy are unclear, but stable polyamine analogs 
may only be effective when given at earlier time points and in less severe forms of necrotizing AP.

\section{Oxidative/Nitrosative and ER Stress}

Oxidative/nitrosative stress is one of the key events in $\mathrm{AP}^{49-51}$ and basic amino acid-induced AP is not an exception. ${ }^{9,35,52,53}$ Thus, it is not surprising that treatments (most commonly administered prophylactically) aiming to reduce reactive oxygen/nitrogen species formation ameliorated the severity of L-arginine-induced AP, although many of these drugs also have anti-inflammatory properties. Such compounds include allopurinol, ${ }^{54}$ melatonin, ${ }^{55,56}$ pyrrolidine dithiocarbamate, ${ }^{57} \mathrm{~N}$-acetylcysteine, ${ }^{58}$ pentoxifylline, ${ }^{59} \alpha, \beta$-amyrin, ${ }^{60}$ selenium, ${ }^{61}$ 4-OH-TEMPO, ${ }^{52,62,63} \mathrm{~N}(\mathrm{G})$-nitro-L-arginine methyl ester, ${ }^{64}$ the medicinal plant Emblica officinalis, ${ }^{65}$ aminoguanidine, ${ }^{66}$ simvastatin, ${ }^{67}$ lawsone,${ }^{25}$ hydrogen-rich saline, ${ }^{68}$ and trimetazidine. ${ }^{28}$

The proinflammatory cytokine levels (like tumor necrosis factor- $\alpha$, interleukin-1 $\beta$, and interleukin-6) are increased, ${ }^{25,28,57,59,60,69}$ whereas anti-inflammatory cytokine concentrations (like that of interleukin-10) are decrea$\operatorname{sed}^{20,55,65}$ in both the serum and pancreas of animals with L-arginine-induced AP. The proinflammatory cytokines and oxidative stress both act to trigger common signal transduction pathways that lead to amplification of the inflammatory cascade, mainly through activation of mitogen-activated protein kinases and NF- $\kappa \mathrm{B}^{70,71}$

Kubisch $e$ e $a l^{37}$ have shown that ER stress is an important early acinar cell event that likely contributes to the development of AP in the L-arginine-induced model in rats. The i.p. injection of $4 \mathrm{~g} / \mathrm{kg}$ L-arginine caused an early activation of ER stress, as indicated by phosphorylation of PERK and its downstream target eIF2 $\alpha$, ATF6 translocation into the nucleus (within $1 \mathrm{~h}$ ), and upregulation of BiP (within $4 \mathrm{~h}$ ). XBP-1 splicing and CHOP expression were observed within $8 \mathrm{~h} .{ }^{37}$ These findings could only partly be confirmed by proteome analysis of the rough ER. ${ }^{33}$ Alterations of rough ER protein levels were found in multiple functional categories including translational regulators, digestive enzymes, chaperones, and cytoskeleton proteins. Overall, the data suggested that the early stages of AP involve alterations in multiple aspects of rough ER functions including the synthesis and processing of digestive enzymes. ${ }^{33}$

\section{The Involvement of the Nervous System}

It has been suggested that L-arginine might induce pancreatitis through activation of the autonomous nervous system. ${ }^{72}$ This hypothesis was based on the observation that $50 \mathrm{mg}$ of orally administered L-arginine provoked enhancement of parasympathetic activity and significant increases of plasma norepinephrine, dopamine, and free serotonin, whereas plasma epinephrine was reduced in healthy subjects. ${ }^{73}$ The authors suggest that these alterations may lead to the parasympathetic hypersecretion of pancreatic juice that could not be drained by the pancreatic ducts. However, this idea needs confirmation in rodents, especially as much higher doses of basic amino acids are used for the induction of experimental pancreatitis and the route of administration is different.

Pain is a leading symptom of AP; however, its pathomechanism remains unclear. Unfortunately, it is particularly difficult to investigate pain in animals. Induction of necrotizing pancreatitis by i.p. injection of $2 \times 2.5 \mathrm{~g} / \mathrm{kg} \mathrm{L}$-arginine caused a 12 -fold increase in the number of spinal neurons expressing the proto-oncogene $c$-fos in laminae I and II of L1, suggesting activation of nociceptive pathways. ${ }^{74}$ L-arginine administration also caused a threefold increase in spontaneous abdominal contractions detected by electromyography, indicative of referred pain. Necrotizing AP activates transient receptor potential vanilloid 1 (a nonselective cation channel mediating inflammatory pain in many tissues) on pancreatic sensory nerves to release neuropeptides like substance $\mathrm{P}$ and calcitonin gene-related peptide in the dorsal horn of the spinal cord, resulting in nociception. ${ }^{74,75}$

\section{Activation of Transcription Factors}

$\mathrm{NF}-\kappa \mathrm{B}$ activation is a central event in the development of AP, and this transcription factor (a complex of dimeric subunits of NF- $\kappa \mathrm{B} 1$ (p50 and its precursor p105), NF- $\kappa \mathrm{B} 2$ (p52 and its precursor p100), p65 (RelA), RelB, and c-Rel) is responsible for regulating the expression of numerous proinflammatory genes. $^{71}$ In contrast to other AP models, NF- $\kappa \mathrm{B}$ activation occurs in later phases of basic amino acid-induced AP. ${ }^{10,57,71}$ Pancreas-specific deletion of $\mathrm{I} \kappa \mathrm{B}-\alpha$ (responsible for regulating NF- $\kappa \mathrm{B}$ activation) resulted in nuclear translocation of RelA and induction of NF- $\kappa \mathrm{B}$-dependent target genes in mice without alteration of pancreatic morphology. ${ }^{76}$ To evaluate the impact of basal activation of pancreatic $\mathrm{NF}-\kappa \mathrm{B}$ on acute inflammation, transgenic mice were subjected to AP induction with large doses of L-arginine. Interestingly, despite the increased basal proinflammatory protein levels, IкB- $\alpha$ deletion reduced the severity of AP, and decreased the levels of cytokine and chemokine levels and trypsin activation in mice after administration of L-arginine. The authors proposed that the protective effect is most likely to result from the highly upregulated serine protease inhibitor 2A (Spi2a) expression in the I $\kappa \mathrm{B}-\alpha$ knockout mice.

Expression of the transcription factors Ptfla, Pdxl, and Hnfl $\alpha$ was found to be decreased in response to L-arginine administration. ${ }^{77}$ The reduced Hnfl $\alpha$ and Ptfla expression was associated with increased proliferation of cells involved in pancreatic repair/regeneration. In addition, $H n f l \alpha-$ and Ptfla-deficient mice showed higher acinar cell proliferation rates than wild-type animals.

Awla et $_{\mathrm{al}} \mathrm{l}^{78}$ explored the involvement of the calcium- and calcineurin-dependent transcription factor nuclear factor of activated $\mathrm{T}$ cells (NFAT) in development of $\mathrm{L}$-arginine induced AP in mice. Administration of the NFAT inhibitor A-285222 or deletion of the NFATC3 gene significantly reduced serum amylase activity, myeloperoxidase activity in 
the pancreas and lung, and edema formation, as well as acinar cell necrosis in L-arginine-induced AP.

\section{Extrapancreatic Complications}

A characteristic feature of acute necrotizing pancreatitis, which can also be observed in basic amino acid-induced AP, is ileus. Zhou et $a l^{79}$ have shown that in L-ornithine-induced $\mathrm{AP}$, this complication may be caused by the damage of myenteric neurons and the interstitial cells of Cajal, the latter of which could be ameliorated by the repetitive s.c. administration of the somatostatin analog octreotide. ${ }^{80}$

High-motility group box protein 1 (HMGB1) A box protein can completely inhibit the proinflammatory response caused by HMGB1. The i.p. administration of the HMGB1 antagonist $A$ box protein had a mild protective effect against L-arginine-induced $(2 \times 2 \mathrm{~g} / \mathrm{kg})$ AP and associated organ injury (pancreas, lung, kidney, and liver) in mice. ${ }^{16}$ The $A$ box treatment also ameliorated L-arginine-induced mortality (the survival rate was $26.7 \%$ in the control group vs $66.7 \%$ in the treatment group). However, the death of mice was unlikely to occur in response to severe AP as mortality mostly happened within $24 \mathrm{~h}$, in the early phase of disease induction.

\section{Mediators of Pancreatic Regeneration and Proliferation}

Pancreatic regeneration starts in parallel and quickly follows the acute inflammatory phase of basic amino acid-induced AP. ${ }^{9,10,81}$ Tissue atrophy and ductuloacinar structures become visible at the sites of previous pancreatic necrosis. Administration of low doses $(1 \mu \mathrm{g} / \mathrm{kg})$ of cholecystokinin octapeptide increased the inflammatory signs of L-arginineinduced AP in the early phase, but subsequently diminished the level of atrophy and accelerated the processes of regeneration. ${ }^{81}$ In a separate set of experiments, we clearly showed that insulin is necessary for the hypertrophic effect of cholecystokinin octapeptide. ${ }^{82}$

Insulin-like growth factor binding protein-4 (IGFBP-4) may play a potential role in pancreatic injury and regeneration in the murine model of L-arginine-induced $\mathrm{AP}^{83}$ In the control mouse pancreatic tissue, IGFBP-4 was mainly immunolocalized to the islets of Langerhans, whereas in animals with AP, the protein was detected in both acinar cells and islets. In addition, the serum IGFBP-4 concentrations nicely correlated with the severity of the AP.

Regenerating gene 4 (Reg4) is a recently discovered member of the regenerating gene family that belongs to the calciumdependent (C-type) lectin superfamily. Reg4 mRNA and protein were markedly upregulated during L-arginineinduced $(2 \times 4 \mathrm{~g} / \mathrm{kg})$ pancreatitis in mice. ${ }^{29}$ Reg4 expression was localized to residual acinar cells around the islets of Langerhans and the regenerating metaplastic epithelium. Administration of recombinant Reg4 protein protected against L-arginine-induced acinar necrosis both in vivo and in vitro. It was also shown that L-arginine induced the expression of antiapoptotic proteins $\mathrm{Bcl}-2$ and $\mathrm{Bcl}-\mathrm{xL},{ }^{30}$ whereas recombinant Reg4 upregulated $\mathrm{Bcl}-2$ and $\mathrm{Bcl}-\mathrm{xL}$ expression by activating the epidermal growth factor receptor/Akt pathway. ${ }^{29}$ The upregulation of $\mathrm{Bcl}-\mathrm{xL}$ correlated inversely with cell necrosis in experimental AP models and in isolated pancreatic acinar cells. ${ }^{29,30}$ Overall, the data suggest that Reg4 may protect against acinar cell necrosis in experimental pancreatitis by enhancing the expression of Bcl-2 and Bcl-xL via activation of the epidermal growth factor receptor/Akt signaling pathway. ${ }^{29}$

Ishiwata et a $l^{84}$ have shown that transient nestin (a stem/ progenitor cell marker) expression occurs in specific cell types during the proliferative stage after recovery from L-arginine-induced AP in rats. Nestin immunoreactivity was detected in a few capillary endothelial cells in some islets in the control rat pancreas. After L-arginine injection, nestin was expressed in proliferating capillary endothelial cells, in stellate cells surrounding ductular structures, and in submesothelial cells. ${ }^{84}$ These results indicate the possible contribution of stem cells and/or progenitor cells to the regenerative capacity of the rat pancreas.

\section{RECENTLY IDENTIFIED THERAPEUTIC TARGETS IN BASIC AMINO ACID-INDUCED PANCREATIC INJURY}

We have provided a long list of compounds affecting oxidative/ nitrosative stress above which can reduce the severity of basicamino-acid-induced pancreatitis (see section Oxidative/ Nitrosative and ER Stress). Administration of the neuronal guidance protein Netrin-1 also significantly reduced plasma amylase activity, pancreatic myeloperoxidase activity, proinflammatory cytokine production, and pancreas and lung tissue damage in L-arginine-induced $\mathrm{AP}^{26}$ Interestingly, netrin-1 administration did not cause significant inhibition of pancreatic NF- $\kappa \mathrm{B}$ activation. In contrast, the antiinflammatory effect of methylprednisolone in L-arginineinduced AP is likely to involve the inhibition of NF- $\kappa \mathrm{B}$ activation in rats..$^{57,85}$ Oxyimatrine administration was found to inhibit plasma tumor necrosis factor- $\alpha$ levels, pancreatic myeloperoxidase activity, and pancreatic injury in L-arginine-induced $\mathrm{AP}^{86}$ In addition, the alkaloid attenuated AP-associated intestinal barrier injury by upregulating the expression of the tight junction protein claudin-1.

Peroxisome proliferator-activated receptors are liganddependent transcription factors that are key regulators of fatty acid and lipoprotein metabolism, glucose homeostasis, cellular proliferation/differentiation, and the immune response. ${ }^{87}$ The peroxisome proliferator-activated receptor- $\gamma$ ligand rosiglitazone ameliorated the severity and improved the regeneration of L-arginine-induced $(2 \times 2 \mathrm{~g} / \mathrm{kg})$ AP in rats. ${ }^{88}$ The beneficial effect of rosiglitazone in case of the latter process is possibly mediated via activation of pancreatic stellate cells, ${ }^{88}$ although inhibition of NF- $\kappa \mathrm{B}$ activation may also be involved, ${ }^{89}$ but this was not investigated by Sidhu et al. ${ }^{88}$

The effect of betacellulin, a ligand of the epidermal growth factor receptor, was investigated in L-arginine-induced AP by using transgenic mice overexpressing betacellulin..$^{90}$ 
Table 1 Intraperitoneal doses of L-arginine-HCl used to induce acute pancreatitis in mice

\begin{tabular}{|c|c|c|c|c|}
\hline Dose $(\mathrm{g} / \mathrm{kg})$ & Time of killing (h) & Pancreatic damage as judged by histology & $\begin{array}{l}\text { Other organ } \\
\text { damage }\end{array}$ & Reference \\
\hline $2 \times 4^{a}$ & $24,48,72,96,120$ & Approx. $25-35 \%$ necrosis at $72-120 \mathrm{~h}$ & Lung & 13,14 \\
\hline $2 \times 4.7$ & 48,72 & $\begin{array}{l}48 \mathrm{~h} \text { : approx. 6/12; } 72 \mathrm{~h} \text { : approx. 4/12; total histological score (based on edema: 0-3, } \\
\text { inflammation: 0-3, acinar cell necrosis: } 0-3 \text {, hemorrhage: } 0-3 \text { ) }\end{array}$ & No data & 18 \\
\hline $2 \times 2^{b}$ & $24,48,72$ & Not analyzed & No data & 15 \\
\hline $2 \times 2.25^{\mathrm{b}}$ & 24,48 & $\begin{array}{l}24 \mathrm{~h}: 7.15 / 13 \text {; } 48 \mathrm{h:} \text { 8.03/13; total histological score (based on edema: } 0-4 \text {, necrosis: } \\
0-4 \text {, hemorrhage: } 0-1 \text {, inflammatory cell infiltration: } 0-4 \text { ) }\end{array}$ & Lung & 16 \\
\hline $2 \times 0.04^{b}$ & $?$ & No damage (just after dendritic cell depletion) & None & 21 \\
\hline
\end{tabular}

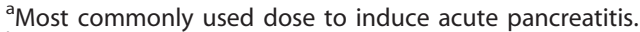

${ }^{b}$ Dose not recommended for acute pancreatitis induction.

Overexpression of betacellulin significantly ameliorated pancreatic necrosis and inflammation caused by injections of L-arginine $(2 \times 4 \mathrm{~g} / \mathrm{kg})$. Most likely, betacellulin protects from AP by activating stress-activated protein kinase as treatment of transgenic mice with the kinase inhibitor SP600125 blocked the beneficial effect of betacellulin. ${ }^{90}$

Toll-like receptor 4 (TLR4) is a pathogen-associated molecular pattern receptor that is essential for recognizing lipopolysaccharide. The involvement of TLR4 in the pathogenesis of L-arginine-induced AP was tested in TLR4 knockout mice. ${ }^{91}$ TLR4 knockout mice treated with large doses of L-arginine exhibited significantly less serum amylase activity, pancreatic myeloperoxidase activity, acinar cell injury, or necrosis with L-arginine as compared with wildtype mice. Morphological changes associated with AP were also less severe in mice that lacked TLR4. As no evidence of either bacteria or lipopolysaccharide in the blood or in pancreatic tissue was found, the authors suggested that TLR4 is important in the pathophysiology of AP, independently of lipopolysaccharide.

Although the use of probiotics in the treatment of human $\mathrm{AP}$ is controversial, ${ }^{92}$ in L-arginine-induced $(2 \times 2.5 \mathrm{~g} / \mathrm{kg}) \mathrm{AP}$, their use in enteral feeding (given by an orogastric tube) was found to be beneficial..$^{93}$ Histological changes of pancreatitis were reduced by treatment with probiotics.

The expression of heat shock proteins (HSPs like HSP27, HSP60, and HSP72) with chaperone effects is increased during the course of $\mathrm{AP}$, and basic amino acid-induced pancreatitis models are not an exception. ${ }^{9}, 10,57,94,95$ The induction of HSPs has also been shown to protect the pancreas against experimental AP. ${ }^{94}$ This was confirmed by Bhagat et $a l^{96}$ who found that induction of HSP70 by treatment with sodium arsenite $(10 \mathrm{mg} / \mathrm{kg})$ significantly ameliorated the changes (pancreatic trypsin and myeloperoxidase activities, edema, acinar cell vacuolization/ damage, and cellular infiltration) associated with L-arginineinduced $(4.5 \mathrm{~g} / \mathrm{kg})$ pancreatitis. The beneficial effect of HSPs is further highlighted by another study by Habtezion et al. ${ }^{97}$ Administration of panhematin, a water-soluble formulation of hemin, induced a rapid upregulation of pancreatic hemeoxygenase-1 (HSP32) in mice. Panhematin-treated animals had significant reduction in serum lipase activity and pancreatic injury in L-arginine-induced AP. Importantly, panhematin offered therapeutic benefit not only when administered early during the course of AP, but also when given in the late phase of disease.

\section{REPETITIVE L-ARGININE INJECTIONS INDUCE CHRONIC PANCREATIC INFLAMMATION IN RATS}

According to the necrosis-fibrosis theory, repeated attacks of AP cause irreversible pancreatic injury and scarring of the tissue that result in extrinsic compression of the pancreatic ducts that may eventually lead to the development of chronic pancreatitis. Thus, it is not surprising that several investigators have explored the use of repetitive L-arginine injections for induction of chronic pancreatitis..$^{98-102}$ In these experiments, rats were injected i.p. with $3-5 \mathrm{~g} / \mathrm{kg} \mathrm{L}$-arginine 1-3 daily for 1 to 6 weeks (Table 2). These protocols typically caused pancreatic acinar cell atrophy, some fibrosis, inflammation, and fat deposition without alterations of ducts or islets. Neural hypertrophy was also reported by González et al. ${ }^{100}$ In addition, the latter authors detected excessive extracellular matrix accumulation and collagen network distortion in the rat pancreas in response to repetitive injections of L-arginine. ${ }^{100}$ Yamaguchi et al ${ }^{102}$ found that the damaged acinar parenchyma caused by repetitive i.p. 
Table 2 Intraperitoneal doses of L-arginine-HCl to model chronic pancreatitis in rats

\begin{tabular}{lll}
\hline Dose & Time of killing (after the last L-arginine-HCl injection) & Reference \\
$2 \times 2.5 \mathrm{~g} / \mathrm{kg}$ on days $1,4,7$, and 10 & 15 days & 100 \\
$21 \times 3 \mathrm{~g} / \mathrm{kg}$ daily followed by $7 \times 3 \mathrm{~g} / \mathrm{kg}$ every 3 days & $24 \mathrm{~h}$ & 99 \\
$3.5 \mathrm{~g} / \mathrm{kg}$ daily for 1 to 4 weeks & From the first to the end of fourth week after the first injection \\
$5 \times 5 \mathrm{~g} / \mathrm{kg}$ at 3-day intervals & $24 \mathrm{~h}$ \\
$5 \mathrm{~g} / \mathrm{kg}$ followed by $3 \times 2.5 \mathrm{~g} / \mathrm{kg}$ over 10 days & $24 \mathrm{~h}$ & 101 \\
\hline
\end{tabular}

injection of near-lethal doses of L-arginine $(5 \times 5 \mathrm{~g} / \mathrm{kg}$ at 3 -day intervals) is dominantly replaced by fatty tissue, and hence the histological appearance is different from that in humans (where fibrotic replacement of the gland is a prominent feature of the disease). Thus, because of the somewhat conflicting results, we believe that the use of repetitive L-arginine injections to model human chronic pancreatitis needs further investigation.

\section{ADVANTAGES AND DISADVANTAGES OF THE BASIC AMINO ACID-INDUCED PANCREATITIS MODELS}

The advantages of using basic amino acid models are relatively straightforward. These models are cheap, technically very simple to carry out, and only require i.p. injection(s). The method of induction is noninvasive and does not require any anesthesia or surgery. They nicely reproduce most laboratory and morphological features of human AP, but not necessarily those of CP. One difference with respect to the morphological features of AP is that the human disease is usually patchy in distribution, whereas basic amino acid-induced AP is relatively homogenous (more so the case in rats). Although the latter characteristic does not reflect the clinical situation, this is beneficial for the investigator as sampling errors are not a problem (like with bile acid-induced AP models).

A frequent critique of the basic amino acid-induced pancreatitis model is their clinical relevance. Although Saka et $a l^{103}$ reported a case of AP possibly caused by arginine consumption, we do not think that this was a likely cause of the disease as the dose of basic amino acid intake (500 mg per day for 5 months) was low. However, even if the induction of AP by basic amino acids is not clinically relevant with respect to the method of induction and/or tissue distribution, this is true for most (if not all) currently available AP models. ${ }^{1}$

As already discussed above in the metabolic alterations section, ${ }^{6}$ another drawback of the basic amino acid-induced AP models is that the obtained results can be variable. In some cases, the sensitivity of individual rats to basic amino acids may be different and low-to-high responders have been detected. ${ }^{32}$

It is rather unfortunate that the dose of basic amino acids inducing AP is very close to the toxic dose and the severity of the disease is difficult to control, especially in mice. The administration of excessive doses of basic amino acids can cause systemic toxicity and death of animals. ${ }^{7,14,32} \mathrm{~A}$ generalized metabolic acidosis caused by large doses of $\mathrm{L}$-arginine- $\mathrm{HCl}$ may cause/contribute to the relatively high mortality. ${ }^{32}$ In rats, i.p. doses above $5 \mathrm{~g} / \mathrm{kg}$ should be avoided because of the considerable mortality rate. In mice, the lethal threshold is not that clear and may be strain dependent as has been noted in cases of cerulein- and choline-deficient ethionine-supplemented diet-induced experimental AP. ${ }^{104}$

Extrapancreatic complications (like pulmonary insufficiency) associated with basic amino acid-induced AP models are mild, ${ }^{22}$ especially if we consider the high degree of pancreatic necrosis. For this reason, and because of the potential systemic toxicity of large doses of basic amino acids, these models are not the most ideal for studies focused on the pathophysiology of extrapancreatic AP-associated events.

\section{SUMMARY AND CONCLUSIONS}

We have come a long way since the initial observations of Mizunuma et $\mathrm{al}^{3}$ concerning the effects of i.p. $5 \mathrm{~g} / \mathrm{kg}$ $\mathrm{L}$-arginine injection on the rat pancreas. In addition, L-ornithine and L-lysine have been shown to induce severe $\mathrm{AP}$ in rats, and higher doses of L-arginine can also induce pancreatitis in mice. Without a doubt, basic amino acidinduced AP models provide a simple and effective way of inducing severe acute necrotizing pancreatitis that mimic laboratory and morphological signs of human AP. Mitochondrial injury may be a key event in the induction of the disease.

Despite their drawbacks, basic amino acid-induced severe AP models provide an alternative to the more commonly used cerulein- (in mice) or bile acid-induced (in mice and rats) acute necrotizing pancreatitis models. Therefore, basic amino acid-induced AP models make it easier for people to test their results in multiple animal models, and thus modelspecific effects can be excluded. ${ }^{1}$

Our knowledge of the disease pathomechanism is incomplete, but it is dynamically increasing, and there is a long and growing list of compounds that are able to ameliorate the severity of basic amino acid-induced AP. As it is still unclear how basic amino acid-induced pancreatic injury evolves, the pathogenesis of the disease needs more investigation, especially concerning the role of mitochondria. 
Hopefully, the obtained results will also help us in understanding and treating human AP.

\section{ACKNOWLEDGMENTS}

We thank Mihály Dezső (Department of Pathology) and Máté Katona (First Department of Medicine) for their help with figure editing. Our research is supported by the Hungarian National Development Agency (TÁMOP4.2.2.A-11/1/KONV-2012-0035, TÁMOP-4.2.2-A-11/1/KONV-2012-0052, and TÁMOP-4.2.2.A-11/1/KONV-2012-0073), the Hungarian Scientific Research Fund (NF105758, NF100677, and K101116), and the Hungarian Academy of Sciences (BO 00174/10/5).

\section{DISCLOSURE/CONFLICT OF INTEREST}

The authors declare no conflict of interest.

1. Hegyi P, Perides G, Steer ML, et al. Commonly Employed Rodent Models of Experimental Acute Pancreatitis: Their Strenghts and Weakness, Relevance to Human Disease, Selection, and Appropriate Use. The Pancreapedia Exocrine Pancreas Knowledge Base 2013; doi:10.3998/panc.2013.4; http://www.pancreapedia.org/ reviews/commonly-employed-rodent-models-of-experimental-acutepancreatitis-their-strengths-and-weakn.

2. Su KH, Cuthbertson C, Christophi C. Review of experimental animal models of acute pancreatitis. HPB 2006;8:264-286.

3. Mizunuma T, Kawamura S, Kishino Y. Effects of injecting excess arginine on rat pancreas. J Nutr 1984;114:467-471.

4. Aho HJ, Koskensalo SM, Nevalainen TJ. Experimental pancreatitis in the rat. Sodium taurocholate-induced acute haemorrhagic pancreatitis. Scand J Gastroenterol 1980;15:411-416.

5. Lampel M, Kern HF. Acute interstitial pancreatitis in the rat induced by excessive doses of a pancreatic secretagogue. Virchows Arch A Pathol Anat Histol 1977;373:97-117.

6. Lombardi B, Estes LW, Longnecker DS. Acute hemorrhagic pancreatitis (massive necrosis) with fat necrosis induced in mice by DL-ethionine fed with a choline-deficient diet. Am J Pathol 1975;79:465-480.

7. Hegyi P, Rakonczay Jr Z, Sári R, et al. L-arginine-induced experimental pancreatitis. World J Gastroenterol 2004;10:2003-2009.

8. Morris Jr. SM. Enzymes of arginine metabolism. J Nutr 2004;134:2743S-2747S, discussion 2765S-2767S.

9. Rakonczay Jr Z, Hegyi P, Dósa S, et al. A new severe acute necrotizing pancreatitis model induced by L-ornithine in rats. Crit Care Med 2008; 36:2117-2127.

10. Biczó G, Hegyi P, Dósa $S$, et al. The crucial role of early mitochondrial injury in L-lysine-induced acute pancreatitis. Antioxid Redox Signal 2011;15:2669-2681.

11. Biczó G, Hegyi P, Dósa $S$, et al. Aliphatic, but not imidazole, basic amino acids cause severe acute necrotizing pancreatitis in rats. Pancreas 2011:40:486-487.

12. Huang W, Chvanov M, Criddle D, et al. L-histidine- but not L-arginineinduced acute pancreatitis in mice involves cyclophilin D-dependent opening of mitochondrial permeability transition pore. Pancreatology 2013;13:S8

13. Dawra $R$, Sharif $R$, Phillips $P$, et al. Development of a new mouse model of acute pancreatitis induced by administration of $\mathrm{L}$-arginine. Am J Physiol Gastrointest Liver Physiol 2007;292:G1009-G1018.

14. Dawra R, Saluja AK. L-arginine-induced experimental acute pancreatitis. The Pancreapedia Exocrine Pancreas Knowledge Base 2012 doi:10.3998/panc.2012.6; http://www.pancreapedia.org/?q=node/1394.

15. Cui HF, Bai ZL. Protective effects of transplanted and mobilized bone marrow stem cells on mice with severe acute pancreatitis. World J Gastroenterol 2003;9:2274-2277.

16. Yuan H, Jin X, Sun J, et al. Protective effect of HMGB1 a box on organ injury of acute pancreatitis in mice. Pancreas 2009;38:143-148.

17. Singh VP, Bhagat L, Navina S, et al. Protease-activated receptor-2 protects against pancreatitis by stimulating exocrine secretion. Gut 2007:56:958-964.

18. Sakai A, Nishiumi S, Shiomi Y, et al. Metabolomic analysis to discover candidate therapeutic agents against acute pancreatitis. Arch Biochem Biophys 2012;522:107-120.
19. Lunova M, Zizer E, Kucukoglu O, et al. Hsp72 overexpression accelerates the recovery from caerulein-induced pancreatitis. PloS One 2012;7:e39972.

20. Huang L, Wang M-H, Cheng Z-Y, et al. Effects of Chai-Qin-Cheng-Q decoction on acute pancreatitis-associated lung injury in mice with acute necrotizing pancreatitis. Chin J Integr Med 2012; e-pub ahead of print.

21. Bedrosian AS, Nguyen AH, Hackman $M$, et al. Dendritic cells promote pancreatic viability in mice with acute pancreatitis. Gastroenterology 2011;141:1915-1926, e1-14.

22. Elder ASF, Saccone GTP, Bersten AD, et al. L-Arginine-induced acute pancreatitis results in mild lung inflammation without altered respiratory mechanics. Exp Lung Res 2011;37:1-9.

23. Kitajima S, Kishino Y. Pancreatic damage produced by injecting excess lysine in rats. Virchows Arch B Cell Pathol Incl Mol Pathol 1985:49:295-305.

24. Abdulla A, Awla D, Hartman $\mathrm{H}$, et al. Role of platelets in experimental acute pancreatitis. Br J Surg 2011;98:93-103.

25. Biradar S, Veeresh B. Protective effect of lawsone on L-Arginine induced acute pancreatitis in rats. Indian J Exp Biol 2013;51:256-261.

26. Chen J, Cai QP, Shen PJ, et al. Netrin-1 protects against L-Arginineinduced acute pancreatitis in mice. PloS One 2012;7:e46201.

27. Merza M, Wetterholm E, Zhang S, et al. Inhibition of geranyIgeranyltransferase attenuates neutrophil accumulation and tissue injury in severe acute pancreatitis. J Leukoc Biol 2013;94: 493-502.

28. Yenicerioglu A, Cetinkaya Z, Girgin M, et al. Effects of trimetazidine in acute pancreatitis induced by L-arginine. Can J Surg J Can Chir 2013;56:175-179.

29. Hu G, Shen J, Cheng L, et al. Reg4 protects against acinar cell necrosis in experimental pancreatitis. Gut 2011;60:820-828.

30. Sung KF, Odinokova IV, Mareninova OA, et al. Prosurvival $\mathrm{Bcl}-2$ proteins stabilize pancreatic mitochondria and protect against necrosis in experimental pancreatitis. Exp Cell Res 2009;315: 1975-1989.

31. Kong XY, Du YQ, Li L, et al. Plasma miR-216a as a potential marker of pancreatic injury in a rat model of acute pancreatitis. World $J$ Gastroenterol 2010;16:4599-4604.

32. Bohus $\mathrm{E}$, Coen $\mathrm{M}$, Keun $\mathrm{HC}$, et al. Temporal metabonomic modeling of I-arginine-induced exocrine pancreatitis. J Proteome Res 2008;7: 4435-4445.

33. Chen X, Sans MD, Strahler JR, et al. Quantitative organella proteomics analysis of rough endoplasmic reticulum from normal and acute pancreatitis rat pancreas. J Proteome Res 2010;9:885-896.

34. Biczó G, Hegyi P, Berczi $S$, et al. Inhibition of arginase activity ameliorates L-arginine-induced acute pancreatitis in rats. Pancreas 2010;39:868-874.

35. Czakó L, Szabolcs A, Vajda A, et al. Hyperlipidemia induced by a cholesterol-rich diet aggravates necrotizing pancreatitis in rats. Eur $J$ Pharmacol 2007:572:74-81.

36. Kishino Y, Takama S, Kitajima S. Ultracytochemistry of pancreatic damage induced by excess lysine. Virchows Arch B Cell Pathol Inc Mol Pathol 1986:52:153-167.

37. Kubisch $\mathrm{CH}$, Sans $\mathrm{MD}$, Arumugam $\mathrm{T}$, et al. Early activation of endoplasmic reticulum stress is associated with arginine-induced acute pancreatitis. Am J Physiol Gastrointest Liver Physiol 2006; 291:G238-G245.

38. Schild L, Matthias R, Stanarius A, et al. Induction of permeability transition in pancreatic mitochondria by cerulein in rats. Mol Cell Biochem 1999;195:191-197.

39. Gukovskaya AS, Gukovsky I, Jung $Y$, et al. Cholecystokinin induces caspase activation and mitochondrial dysfunction in pancreatic acinar cells. Roles in cell injury processes of pancreatitis. J Biol Chem 2002;277:22595-22604.

40. Shen J, Wan R, Hu G, et al. Involvement of thrombopoietin in acinar cell necrosis in L-arginine-induced acute pancreatitis in mice. Cytokine 2012;60:294-301.

41. Hartman H, Abdulla A, Awla D, et al. P-selectin mediates neutrophil rolling and recruitment in acute pancreatitis. Br J Surg 2012;99: 246-255.

42. Saeki K, Kanai T, Nakano M, et al. CCL2-induced migration and SOCS3mediated activation of macrophages are involved in cerulein-induced pancreatitis in mice. Gastroenterology 2012;142:1010-1020, e9. 
43. Moreira M, Matias JEF, Souza de CJF, et al. Action of tacrolimus in arginine induced experimental acute pancreatitis. Rev Colégio Bras Cir 2011:38:260-265.

44. Hyvönen MT, Merentie M, Uimari A, et al. Mechanisms of polyamine catabolism-induced acute pancreatitis. Biochem Soc Trans 2007; 35:326-330.

45. Alhonen L, Parkkinen JJ, Keinanen T, et al. Activation of polyamine catabolism in transgenic rats induces acute pancreatitis. Proc Natl Acad Sci USA 2000;97:8290-8295.

46. Herzig K-H, Jänne J, Alhonen L. Acute pancreatitis induced by activation of the polyamine catabolism in gene-modified mice and rats overexpressing spermidine/spermine N1-acetyltransferase. Scand J Gastroenterol 2005;40:120-121.

47. Hyvönen MT, Herzig $\mathrm{KH}$, Sinervirta $\mathrm{R}$, et al. Activated polyamine catabolism in acute pancreatitis: alpha-methylated polyamine analogues prevent trypsinogen activation and pancreatitisassociated mortality. Am J Pathol 2006;168:115-122.

48. Biczó $G$, Hegyi $P$, Sinervirta $R$, et al. Characterization of polyamine homeostasis in l-ornithine-induced acute pancreatitis in rats. Pancreas 2010;39:1047-1056.

49. Booth DM, Mukherjee $\mathrm{R}$, Sutton $\mathrm{R}$, et al. Calcium and reactive oxygen species in acute pancreatitis: friend or foe? Antioxid Redox Signal 2011;15:2683-2698.

50. Leung PS, Chan YC. Role of oxidative stress in pancreatic inflammation. Antioxid Redox Signal 2009;11:135-165.

51. Hegyi $P$, Rakonczay Jr. Z. The role of nitric oxide in the physiology and pathophysiology of the exocrine pancreas. Antioxidants Redox Signal 2011;15:2723-2741.

52. Jacewicz D, Dabrowska A, Wyrzykowski D, et al. A novel biosensor for evaluation of apoptotic or necrotic effects of nitrogen dioxide during acute pancreatitis in rat. Sensors 2010;10:280-291.

53. Varga IS, Matkovics B, Czako L, et al. Oxidative stress changes in L-arginine-induced pancreatitis in rats. Pancreas 1997:14:355-359.

54. Czakó L, Takács T, Varga IS, et al. Involvement of oxygen-derived free radicals in L-arginine-induced acute pancreatitis. Dig Dis Sci 1998;43: 1770-1777.

55. Sidhu S, Pandhi $P$, Malhotra S, et al. Melatonin treatment is beneficial in pancreatic repair process after experimental acute pancreatitis. Eur J Pharmacol 2010;628:282-289.

56. Szabolcs A, Reiter RJ, Letoha $T$, et al. Effect of melatonin on the severity of L-arginine-induced experimental acute pancreatitis in rats. World J Gastroenterol 2006;12:251-258.

57. Rakonczay Jr Z, Jármay K, Kaszaki J, et al. NF-kappaB activation is detrimental in arginine-induced acute pancreatitis. Free Radic Biol Med 2003;34:696-709.

58. Onur E, Paksoy M, Baca B, et al. Hyperbaric oxygen and $\mathrm{N}$-acetylcysteine treatment in L-arginine-induced acute pancreatitis in rats. J Investig Surg 2012;25:20-28.

59. Abdin AA, El-Hamid MAA, El-Seoud SHA, et al. Effect of pentoxifylline and/or alpha lipoic acid on experimentally induced acute pancreatitis. Eur J Pharmacol 2010;643:289-296.

60. Melo CM, Carvalho KMMB, Neves JCS, et al. Alpha,beta-amyrin, a natural triterpenoid ameliorates L-arginine-induced acute pancreatitis in rats. World J Gastroenterol 2010;16:4272-4280.

61. Hardman J, Jamdar S, Shields C, et al. Intravenous selenium modulates L-arginine-induced experimental acute pancreatitis. JOP 2005;6:431-437.

62. Dabrowska A, Jacewicz D, Łapińska A, et al. Pivotal participation of nitrogen dioxide in L-arginine induced acute necrotizing pancreatitis: protective role of superoxide scavenger 4-OH-TEMPO. Biochem Biophys Res Commun 2005;326:313-320.

63. Krajewski E, Krajewski J, Spodnik JH, et al. Changes in the morphology of the acinar cells of the rat pancreas in the oedematous and necrotic types of experimental acute pancreatitis. Folia Morphol 2005;64:292-303.

64. Takács T, Czakó L, Morschl E, et al. The role of nitric oxide in edema formation in L-arginine-induced acute pancreatitis. Pancreas 2002;25:277-282.

65. Sidhu $S$, Pandhi $P$, Malhotra $S$, et al. Beneficial effects of Emblica officinalis in L-arginine-induced acute pancreatitis in rats. J Med Food 2011;14:147-155.

66. Shields CJ, Delaney CP, Winter DC, et al. Induction of nitric oxide synthase is a key determinant of progression to pulmonary injury in experimental pancreatitis. Surg Infect 2006;7:501-511.
67. Matalka II, Mhaidat NM, Fatlawi LA. Antioxidant activity of simvastatin prevents L-arginine-induced acute toxicity of pancreas. Int J Physiol Pathophysiol Pharmacol 2013;5:102-108.

68. Chen $H$, Sun YP, Li Y, et al. Hydrogen-rich saline ameliorates the severity of I-arginine-induced acute pancreatitis in rats. Biochem Biophys Res Commun 2010;393:308-313.

69. Czakó L, Takács T, Varga IS, et al. The pathogenesis of L-arginine induced acute necrotizing pancreatitis: inflammatory mediators and endogenous cholecystokinin. J Physiol Paris 2000;94:43-50.

70. Pereda J, Sabater L, Aparisi L, et al. Interaction between cytokines and oxidative stress in acute pancreatitis. Curr Med Chem 2006;13: 2775-2787.

71. Rakonczay Jr Z, Hegyi P, Takács T, et al. The role of NF-kappaB activation in the pathogenesis of acute pancreatitis. Gut 2008;57: 259-267.

72. Lechin F, van der Dijs B. Arginine-induced pancreatitis: involvement of the autonomic nervous system? Am J Physiol Gastrointest Liver Physiol 2008;294:G1450-G1451, author reply G1452.

73. Lechin F, Dijs B, Baez S, et al. The effects of oral arginine on neuroautonomic parameters in. J Appl Res 2006;6:201-213.

74. Wick EC, Hoge SG, Grahn SW, et al. Transient receptor potential vanilloid 1, calcitonin gene-related peptide, and substance $P$ mediate nociception in acute pancreatitis. Am J Physiol Gastrointest Liver Physiol 2006;290:G959-G969.

75. Wick EC, Pikios S, Grady EF, et al. Calcitonin gene-related peptide partially mediates nociception in acute experimental pancreatitis. Surgery 2006;139:197-201.

76. Neuhöfer $\mathrm{P}$, Liang $\mathrm{S}$, Einwächter $\mathrm{H}$, et al. Deletion of $\mathrm{I} \kappa \mathrm{B} \alpha$ activates RelA to reduce acute pancreatitis in mice through up-regulation of Spi2A. Gastroenterology 2013;144:192-201.

77. Molero X, Vaquero EC, Flández $\mathrm{M}$, et al. Gene expression dynamics after murine pancreatitis unveils novel roles for $\mathrm{Hnf} 1 \alpha$ in acinar cell homeostasis. Gut 2012;61:1187-1196.

78. Awla D, Zetterqvist AV, Abdulla A, et al. NFATc3 regulates trypsinogen activation, neutrophil recruitment, and tissue damage in acute pancreatitis in mice. Gastroenterology 2012;143:1352-1360, e1-7.

79. Zhou H, Liu L, Bai Y, et al. Damage of the interstitial cells of Cajal and myenteric neurons causing ileus in acute necrotizing pancreatitis rats. Surgery 2011;149:262-275.

80. Zhou H, Gao J, Wu W, et al. Octreotide ameliorates intestinal dysmotility by interstitial cells of Cajal protection in a rat acute necrotizing pancreatitis model. Pancreas 2011;40:1226-1233.

81. Hegyi $\mathrm{P}$, Takács T, Jármay K, et al. Spontaneous and cholecystokininoctapeptide-promoted regeneration of the pancreas following L-arginine-induced pancreatitis in rat. Int J Pancreatol 1997;22: 193-200.

82. Hegyi P, Rakonczay Jr Z, Sari $R$, et al. Insulin is necessary for the hypertrophic effect of cholecystokinin-octapeptide following acute necrotizing experimental pancreatitis. World J Gastroenterol 2004:10:2275-2277.

83. Shen JQ, Shen J, Wang XP. Expression of insulin-like growth facto binding protein-4 (IGFBP-4) in acute pancreatitis induced by L-arginine in mice. Acta Histochem 2012;114:379-385.

84. Ishiwata $T$, Kudo $M$, Onda $M$, et al. Defined localization of nestinexpressing cells in L-arginine-induced acute pancreatitis. Pancreas 2006:32:360-368.

85. Paszt A, Eder K, Szabolcs A, et al. Effects of glucocorticoid agonist and antagonist on the pathogenesis of L-arginine-induced acute pancreatitis in rat. Pancreas 2008;36:369-376.

86. Zhang $Z$, Wang $Y$, Dong $M$, et al. Oxymatrine ameliorates L-arginine-induced acute pancreatitis in rats. Inflammation 2012;35: 605-613.

87. Menendez-Gutierrez MP, Roszer T, Ricote M. Biology and therapeutic applications of peroxisome proliferator-activated receptors. Curr Top Med Chem 2012;12:548-584.

88. Sidhu S, Pandhi $\mathrm{P}$, Malhotra $\mathrm{S}$, et al. Rosiglitazone promotes pancreatic regeneration in experimental model of acute pancreatitis. Fundam Clin Pharmacol 2011;25:237-247.

89. Neher MD, Weckbach S, Huber-Lang MS, et al. New insights into the role of peroxisome proliferator-activated receptors in regulating the inflammatory response after tissue injury. PPAR Res 2012 2012:728461. 
90. Dahlhoff $M$, Algül $H$, Siveke JT, et al. Betacellulin protects from pancreatitis by activating stress-activated protein kinase. Gastroenterology 2010;138:1585-1594, 1594.e1-3.

91. Sharif R, Dawra R, Wasiluk K, et al. Impact of toll-like receptor 4 on the severity of acute pancreatitis and pancreatitis-associated lung injury in mice. Gut 2009;58:813-819.

92. Besselink MGH, van Santvoort HC, Buskens E, et al. Probiotic prophylaxis in predicted severe acute pancreatitis: a randomised, double-blind, placebo-controlled trial. Lancet 2008;371:651-659.

93. Muftuoglu MAT, Isikgor $S$, Tosun $S$, et al. Effects of probiotics on the severity of experimental acute pancreatitis. Eur J Clin Nutr 2006;60: 464-468.

94. Rakonczay Jr Z, Takács T, Boros I, et al. Heat shock proteins and the pancreas. J Cell Physiol 2003;195:383-391.

95. Tashiro $M$, Schäfer $C$, Yao $H$, et al. Arginine induced acute pancreatitis alters the actin cytoskeleton and increases heat shock protein expression in rat pancreatic acinar cells. Gut 2001:49:241-250.

96. Bhagat L, Singh VP, Dawra RK, et al. Sodium arsenite induces heat shock protein 70 expression and protects against secretagogueinduced trypsinogen and NF-kappaB activation. J Cell Physiol 2008:215:37-46
97. Habtezion A, Kwan R, Akhtar $\mathrm{E}$, et al. Panhematin provides a therapeutic benefit in experimental pancreatitis. Gut 2011;60:671-679.

98. Delaney CP, McGeeney KF, Dervan P, et al. Pancreatic atrophy: a new model using serial intra-peritoneal injections of L-arginine. Scand J Gastroenterol 1993;28:1086-1090.

99. Fredstrom SB, Jessurun J, Gallaher DD. Pancreatitis induced in rats by repetitive administration of L-arginine. Pancreas 2009;38:344-345.

100. González AM, Garcia T, Samper E, et al. Assessment of the protective effects of oral tocotrienols in arginine chronic-like pancreatitis. Am J Physiol Gastrointest Liver Physiol 2011;301:G846-G855.

101. Weaver C, Bishop AE, Polak JM. Pancreatic changes elicited by chronic administration of excess L-arginine. Exp Mol Pathol 1994;60:71-87.

102. Yamaguchi T, Kihara $Y$, Taguchi $M$, et al. Persistent destruction of the basement membrane of the pancreatic duct contributes to progressive acinar atrophy in rats with experimentally induced pancreatitis. Pancreas 2005;31:365-372.

103. Saka $M$, Tüzün $A$, Ateş $Y$, et al. Acute pancreatitis possibly due to arginine use: a case report. Turk J Gastroenterol 2004;15:56-58.

104. Wang J, Ohmuraya M, Suyama K, et al. Relationship of straindependent susceptibility to experimentally induced acute pancreatitis with regulation of Prss1 and Spink3 expression. Lab Invest 2010;90:654-664. 